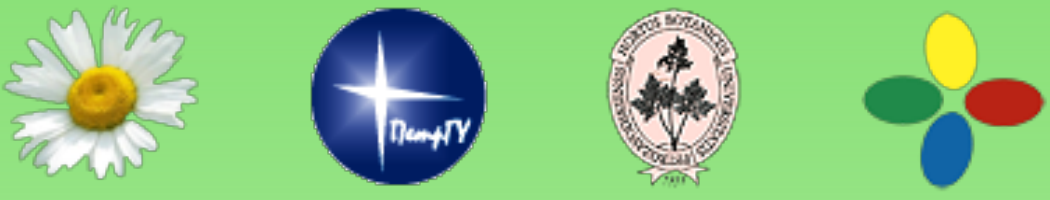

\section{HORTUS BOTANICUS}

Международный электронный журнал ботанических садов

\section{$11 / 2016$}

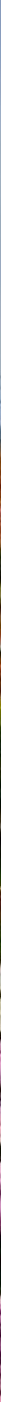


Информационно-аналитический центр Совета ботанических садов России при Ботаническом саде Петрозаводского государственного университета

\section{HORTUS BOTANICUS}

Международный электронный журнал ботанических садов

\section{$11 / 2016$}

ISSN 1994-3849

Эл № ФС 77-33059 от 11.09.2008

Главный редактор
А. А. Прохоров

Редакционный совет

Редакционная коллегия

Редакция

П. Вайс Джексон

Г. С. Антипина

К. А. Васильева

А. С. Демидов

Е. М. Арнаутова

А. В. Еглачева

T. С. Маммадов

А. В. Бобров

С. М. Кузьменкова

В. Н. Решетников

Ю. К. Виноградова

А. Г. Марахтанов

Т. М. Черевченко

Е. В. Голосова

Ю. Н. Карпун

В. Я. Кузеванов

Е. Ф. Марковская

Ю. В. Наумцев

Е. В. Спиридович

А. И. Шмаков

\section{Адрес редакции}

185910, Республика Карелия, г. Петрозаводск, ул. Красноармейская, 31, каб. 12.

E-mail: hortbot@gmail.com

http://hb.karelia.ru

(c) 2001 - 2016 A. A. Прохоров

\section{На обложке:}

На Балу хризантем в Никитском ботаническом саду (фото Ю. Югансона)

\section{Разработка и техническая поддержка}

Отдел объединенной редакции научных журналов ПетрГУ, РЦ НИТ ПетрГу, Ботанический сад ПетрГу 
Ботанические сады: история и современность

\section{Экологический ресурс и его реализация в Ботаническом саду Воронежского государственного университета}

\section{ВОРОНИН \\ Андрей Алексеевич}

\section{МУКОВНИНА}

Зоя Павловна

\section{KOMOBA \\ Алла Витальевна}

\section{Ключевые слова:}

наука, образование, социальная деятельность, экологический ресурс, интродукция, научнообразовательный потенциал, ботанический сад, естественные и рукотворные экосистемы, экологопознавательная тропа, коллекции, экскурсии
Воронежский государственный университет, vsubotsad@mail.ru

Воронежский государственный университет, botsad.vsu@mail.ru

Воронежский государственный университет, botsad.vsu@mail.ru

\begin{abstract}
Аннотация:
Рассмотрены составляющие экологического ресурса Ботанического сада Воронежского государственного университета в связи с его интродукционной деятельностью и научно-образовательным процессом. Это коллекции, экспозиции и участки естественной растительности, характерные для лесостепи. Приведены примеры использования экологического ресурса в научнообразовательном процессе: исследование флоры сосудистых растений, мхов, лишайников, грибов, фауны; изучение эколого-биологических особенностей коллекционных растений с приоритетом на редкие и исчезающие виды; проведение полевых учебных и производственных практик; экскурсии, беседы. Показаны возможности ботанического сада по формированию туристско-экскурсионного потенциала, а вместе с этим формирование экологического мышления и культуры. Выделены и описаны 13 пунктов эколого-познавательной тропы, охватывающей все естественные экосистемы и старовозрастные дендрологические коллекции, старые залежи. Названы темы экскурсий по всем другим коллекциям Ботанического сада. Определены реальные перспективы развития научных исследований.
\end{abstract}

Рецензент: В. Я. Кузеванов

Получена: 01 октября 2016 года

Термин экологический ресурс используют специалисты разных профилей, вкладывая в его определение свои дисциплинарные понятия. Иркутские ученые (Кузеванов, Никулина, 2016) проанализировали их и, обобщив, предложили свое определение, которое применимо ко всем ботаническим садам. Разнообразное использование ресурсов в ботанических садах показано в работах Л. Н. Андреева и др. (2006), В. Я. Кузеванова и С. В. Сизых (2005) и др.

Университетские ботанические сады - это интродукционные центры по введению новых полезных видов растений разных эколого-географических зон мира, изучению и размножению их для практического использования. Одновременно с этим, они выполняют образовательные задачи своих учебных заведений. Кроме того, на XII Международном ботаническом конгрессе и во всех более поздних материалах, в частности, в рамках Международной программы ботанических садов по охране растений 
(2000) было названо еще одно важнейшее направление деятельности ботанических садов - выполнение Конвенции по биоразнообразию. Оно включает сохранение генетических фиторесурсов и рациональное использование их in situ (в природной обстановке) и ех situ (в коллекциях), экологическое просвещение, формирование экологической культуры.

Для выполнения своих задач ботанические сады создают коллекции, экспозиции, гербарий, питомники, теплицы, лаборатории. Вместе они составляют экологический ресурс, к которому следует отнести естественные экосистемы и нематериальные ценности: визуальную привлекательность, положительные эмоции, чистый воздух.

Практически все ботанические сады имеют одинаковый базовый ресурс. Однако в деталях могут быть значительные расхождения, особенно в его реализации, что связано с человеческим фактором. Знание особенностей использования экологического ресурса в каждом конкретном ботаническом саду всегда уникально и актуально. В этой связи рассмотрим реализацию его в Ботаническом саду им. проф. Б. М. Козо-Полянского (БС) Воронежского государственного университета (ВГУ).

В Ботаническом саду Воронежского госуниверситета (БС ВГу) с начала его организации в 1937 г. приступили к работе по формированию коллекционных фондов научного и экспозиционного назначения. Для этого были созданы коллекции новых экономических культур, дендрологическая, декоративнотравянистых растений, тропических и субтропических культур, природной флоры и растительности Центрального Черноземья, семенная лаборатория, опылительная пасека. Кроме того, очень важно то, что в Ботаническом саду ВГУ около половины всей площади из 72,3 га занято природными экосистемами, уникальными для урбанизированной территории. Они включают участки коренной и порослевой байрачной дубравы с Quercus robur L., осинники с Populus tremula L. (рис. 1), терновники с Prunus spinosa L. (рис. 2), вишарники c Cerasus vulgaris Risso и разнотравно-злаковые лугово-степные склоны, характерные для средней лесостепи (Муковнина и др., 2005; Щеглов, Муковнина, 2007). В 1970-1980 гг. в них было выявлено 426 видов растений (Муковнина, 1988). К настоящему времени список их пополнился 237 видами за счет адвентиков. Они получили распространение в результате сокращения сбора семян интродуцентов, отсутствия сенокошения и др. агротехнических мероприятий в годы экономических реформ 1990-х годов (Лепешкина, Воронин, 2014).
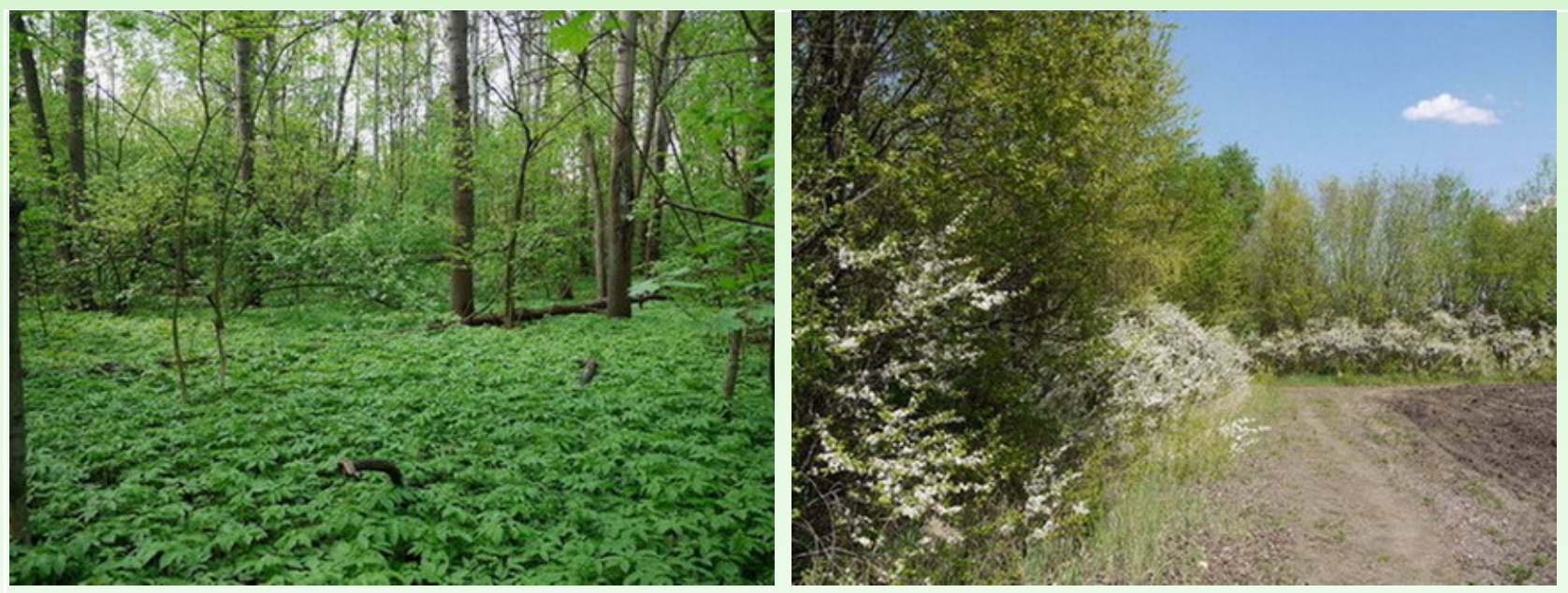

Рис. 1. Снытьево-кленовый осинник в БС ВГУ.

Fig. 1. Populus tremula \pm Acer campestris Aegopodium podagraria, in situ, in the BG of the VSU.
Рис. 2. Терновники в БС ВГУ.

Fig. 2. Thickets of blackthorn, in situ, in the BG of the VSU.

В процессе работы в Ботаническом саду используются традиционные интродукционные методы. Среди них наиболее разнообразны и детально разработаны методы предварительного выбора интродуцентов и методы непосредственной работы с ними. 
Естественные экосистемы БС являются хранилищем генофонда растений природной флоры Центрального Черноземья. Изучение биоразнообразия их природных компонентов дает богатый материал для научных исследований. Аспиранты разных специальностей биолого-почвенного факультета ВГУ выявили состав флоры мхов, лишайников, грибов и фауну (позвоночных и беспозвоночных животных). Полученные данные вошли в их кандидатские диссертации (Воронин и др., 2014). В то же время БС прекрасное место полевых студенческих практик для почвоведов, биологов, географов, экологов Воронежского госуниверситета и других ВУЗов города (Лепешкина и др., 2011).

Рукотворные коллекции Ботанического сада тоже всегда служили источником живых наглядных пособий при изучении лекарственных, декоративных, медоносных и других полезных растений (Николаев, 1977; Воронин и др., 2013; Комова и др., 2015). Наиболее широко его коллекции используются кафедрой генетики, селекции и теории эволюции Воронежского госуниверситета (Машкин, 1994). Студенты и аспиранты кафедры изучали злаковые (Poaceae) и бобовые (Leguminosae) культуры отдела новых экономических культур. Особое внимание уделялось высокобелковой культуре coe посевной (Glycine max (L.) Merr). На базе плодовых коллекций были созданы 18 сортов черешни (Prunus avium (L.) L.). Изучены биология индивидуального развития и культивирования лимонника китайского (Schisandra chinensis (Turcz.) Ваill.), физиолого-биохимические и морфо-физиологические показатели зимостойкости представителей семейства Rosaceae, в частности, видов и сортов вишни обыкновенной (Cerasus vulgaris Risso). Коллекция лекарственных растений БС является постоянной учебной базой для фармацевтического факультета, где студенты третьего курса проходят учебные практики по фармакогнозии и производственную по ресурсоведению (Кузнецов и др., 2015). На базе коллекции «Систематикум природной флоры Центрально-Черноземного региона» выполняются десятки курсовых и дипломных работ по выявлению эколого-биологических особенностей редких и охраняемых растений (Adonis vernalis L., Androsace villosa L., Schivereckia podolica (Besser) Andrz. ex DC. и др.) (Муковнина и др., 2014). Важным прикладным аспектом проведения практик являются дисциплины, связанные с озеленением населенных пунктов: цветоводство, ландшафтный дизайн, вертикальное озеленение, ландшафтное проектирование. В результате сотрудничества с Воронежской государственной лесотехнической академией были выполнены дипломные проекты по озеленению и благоустройству разных коллекционных участков Ботанического сада.

Из вышесказанного видно, что природные и рукотворные экосистемы (коллекции и экспозиции) БС реализуются как естественные лаборатории для научных исследований, учебных практик, как основа для выполнения курсовых, дипломных и диссертационных работ, как места для лекций и бесед на экологические темы. Кроме того, в помощь студентам, научным сотрудникам в Ботаническом саду функционируют семенная и биотехнологическая лаборатории, гербарий, библиотека, система обработки информации.

В современных экономических условиях ботанические сады все больше вовлекаются в прагматические отношения с окружающей действительностью. В связи с этим в ботанических садах одним из актуальных вопросов является формирование туристско-экскурсионного потенциала. Ботанический сад ВГУ, особо охраняемая природная территория с его уникальными природными экосистемами, характерными для лесостепи, богатыми коллекциями, в том числе местной флоры, фактически представляет собой зеленый остров, музей под открытым небом, оазис в черте города. Используя этот ресурс, БС может стать значимым звеном Большой экологической тропы Воронежа как привлекательный объект для тематических экскурсий. Экскурсии по коллекциям и экспозициям для школьников, студентов и всех желающих всегда были неотъемлемой частью его работы. Ежегодно в мае-сентябре проводилось более 150 экскурсий с охватом 3000-4000 посетителей. В настоящее время в БС в практику экологического образования входят экологические маршруты (Лепешкина и др., 2012). Приведем пример одного из них с наиболее протяженной эколого-познавательной тропой, охватывающей основные естественные экосистемы с прилегающими дендрологическими коллекциями и экспозициями (Воронин и др., 2014) (рис. 3). Степень подробности сведений, сообщаемых на протяжении всего маршрута, зависит от интересов, возраста и уровня подготовленности посетителей. В рассказе обязательно уделяется внимание теме редких видов растений и их охране. 


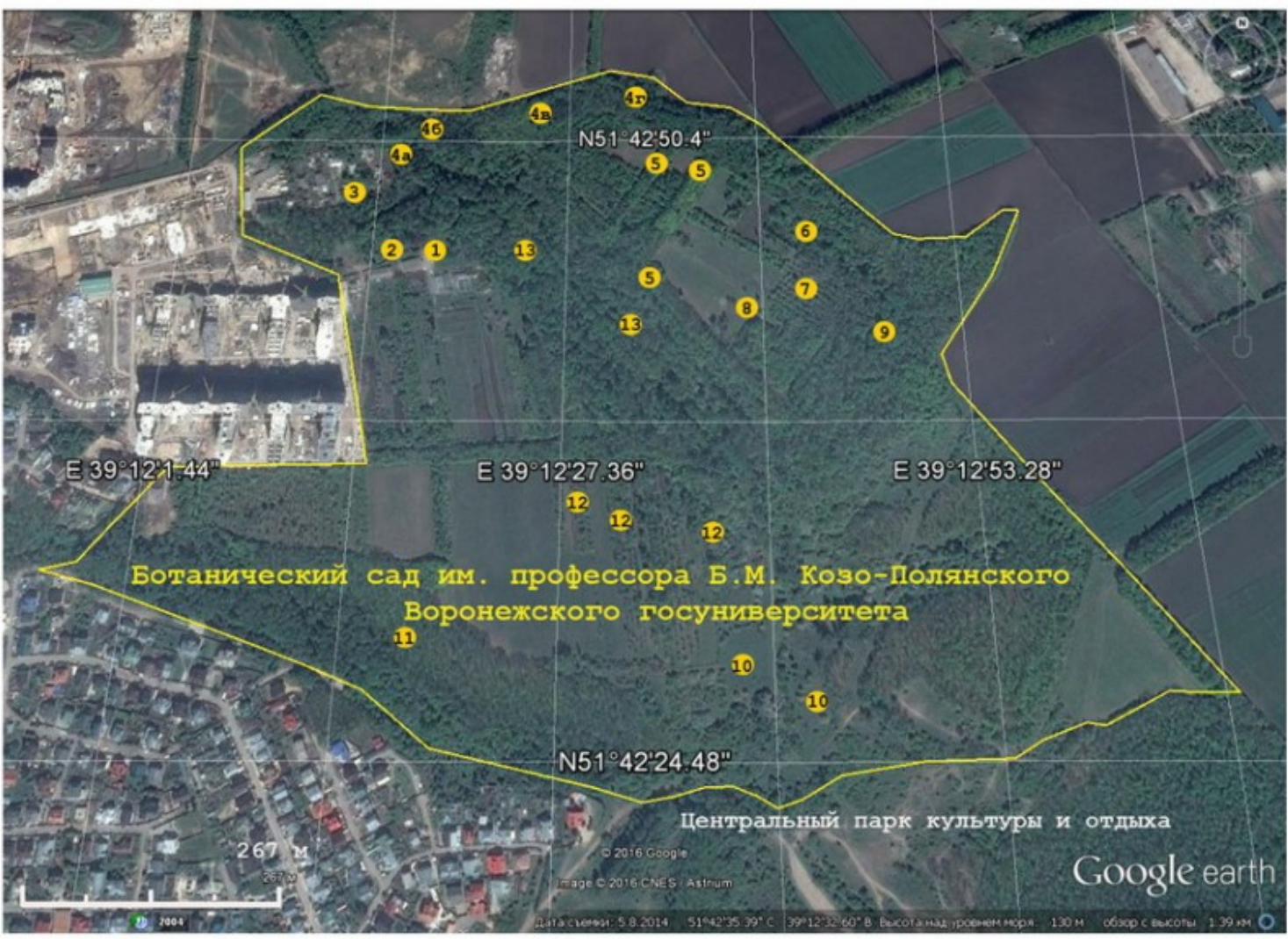

\section{УСЛОВНЫЕ ОБОЗНАЧЕНИЯ :}

1. Место для ознакомительной беседы; 2. Мемориал; 3. Историческая часть

Ботанического сада; 4а. Туэтум; 4б. Сухой бор; 4в. Пинетум; 42. Лиственничник;

5. Лесополосы; 6. Арборетум; 7. Мичуринский сад; 8. Залежные участки; 9. Заповедная дубрава; 10. Травянистые склоны; 11. Байрачная дубрава; 12. Коллекция диких плодовых и косточковых культур; 13. Географический дендропарк.

Рис. 3. Пункты маршрута экологической тропы по естественным и антропогенным экосистемам Ботанического сада ВГу.

Fig. 3. Points of a route of an ecological track on natural and anthropogenous ecosystems in the Botanical Garden of the VSU.

Пункт 1. Место для ознакомительной беседы (рис. 3, п. 1)

Прежде чем начать движение по маршруту, проводим вводную беседу возле административнолабораторного корпуса, вокруг дерева дуба черешчатого (Quercus robur L.), возраст которого 250-300 лет (рис. 4). В 2014 г. решением сертификационной комиссии Всероссийской программы «Деревья памятники живой природы» он был внесен в Национальный реестр старовозрастных деревьев России. Здесь оборудовано место, предназначенное для лекций студентам перед практическими занятиями, бесед со школьниками и другими посетителями Сада. Независимо от контингента, конкретной темы кратко рассказывается о ботанических садах мира, России, об их целях и задачах, о создании Ботанического сада Воронежского госуниверситета. Приводятся сведения о географическом положении Сада, особенностях его окрестностей, о его статусе государственного научно-исследовательского учреждения и охраняемого памятника природы. Особое внимание уделяется рассказу об интродукционной работе, достижениях. 


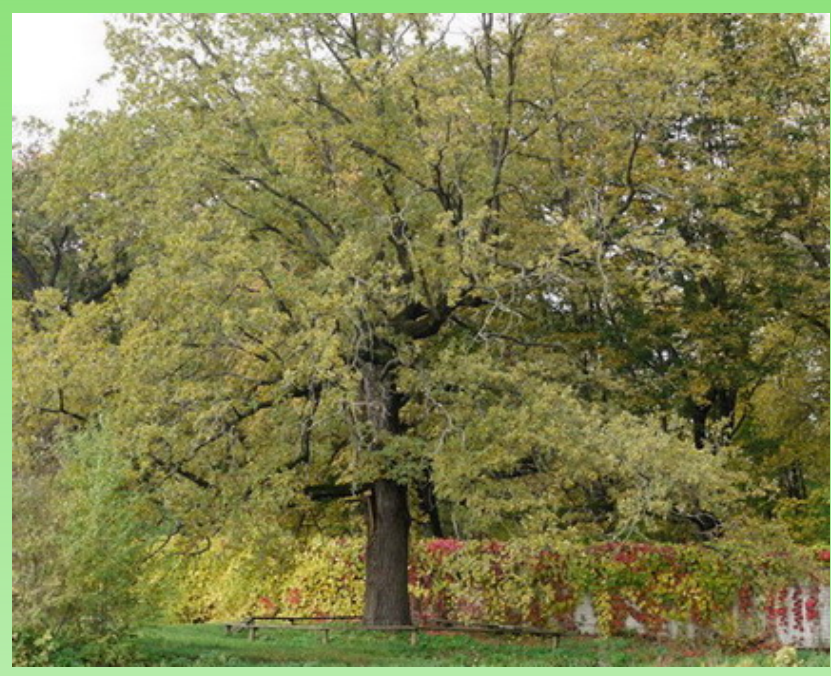

Рис. 4. Место для ознакомительной беседы у дуба черешчатого (Quercus robur L.) в БС ВГУ.

Fig. 4. A place for information session at an Quercus robur L. in the BG of the VSU.

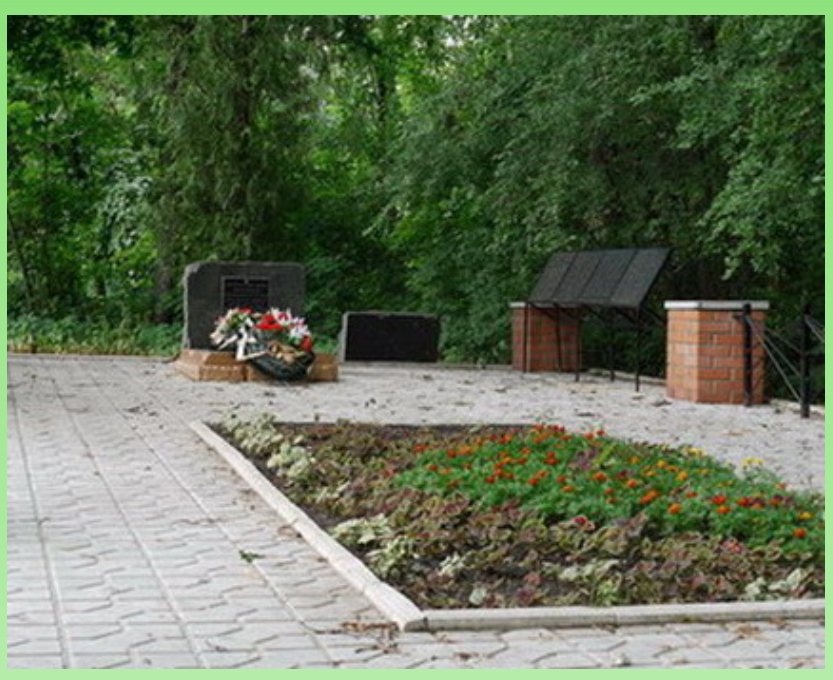

Рис. 5. Памятник воинам и сотрудникам БС ВГу.

Fig. 5. A monument to soldiers and employees of the BG of the VSU. 5)

Пункт 2. Мемориал погибшим воинам Красной Армии и сотрудникам Сада (рис. 3, п. 2; рис.

О военных событиях, происходивших в июле 1942 г. - январе 1943 г. на территории БС до сих пор свидетельствуют многочисленные окопы, воронки, найденные остатки оружия, каски, солдатские медальоны. В списках ботанических садов, наиболее пострадавших в годы Великой отечественной войны, числится и Ботанический сад ВГу (Николаев, 1977).

Сотрудники БС, проживавшие на его территории, во время бомбежки укрывались в подвале овощехранилища, там же были и раненые красноармейцы. В результате прямого попадания артиллерийского снаряда все находившиеся там люди погибли. Очевидцем этого была молодая рабочая БС, которая с двумя детьми за несколько минут до трагедии покинула овощехранилище. После освобождения Воронежа от фашистов она продолжала работать в БС.

Пункт 3. Историческая часть Ботанического сада (рис. 3, п. 3)

В 1901-1918 гг. большая часть территории Сада являлась дачей любителя-дендролога купца Н. Ф. Петрова. В данном пункте располагался его дом, от которого до наших дней остались остатки фундамента, ложе фонтана из одесского ракушечника, сохранилась каменистая горка и часть мраморных ступеней (рис. 6), ведущих к пруду, расположенному ниже. Пруд (рис. 7) находится в центре микрозаповедника «Старая дубрава» в разнотравно-кленовом дубняке (Quercus robur - Acer platanoides variiherbitas), где отмечено около 100 видов растений (рис. 8). Основу его составляют дубы, возраст которых 50-200 лет и более. Годичные кольца можно было посчитать на спилах нескольких старых деревьев, которые упали во время сильных ветров. Весной здесь обильно цветут пролеска сибирская (Scilla siberica Andrews), хохлатка плотная (Corydalis solida Sw.), медуница лекарственная (Pulmonaria officinalis L.), яснотка крапчатая (Lamium maculatum L.). 


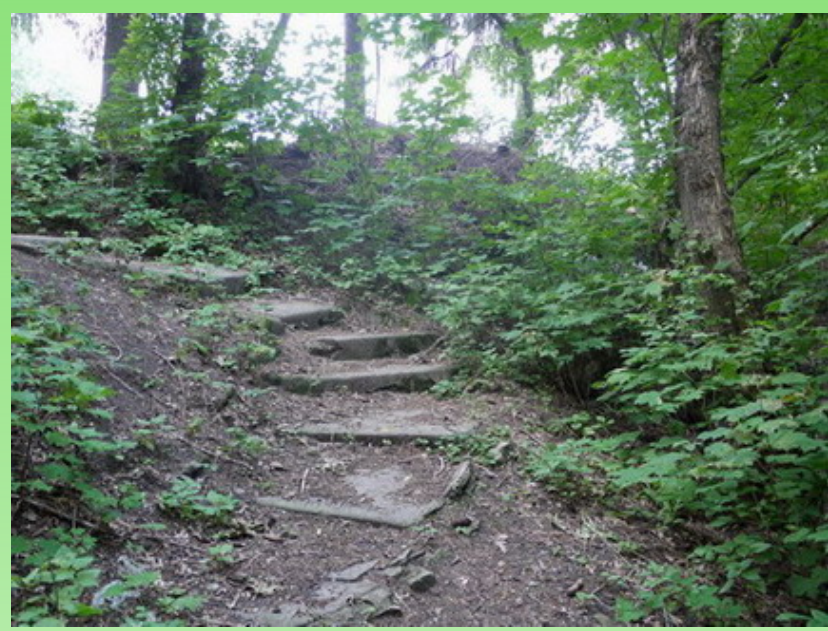

Рис. 6. Старинные мраморные ступени в исторической части БС.

Fig. 6. Ancient marble steps in historical part of the BG.

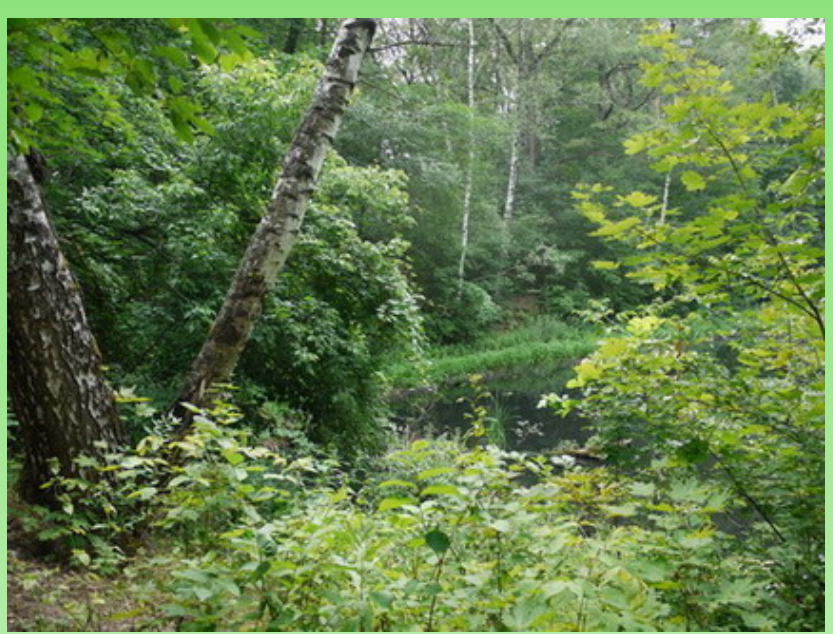

Рис. 7. Пруд в исторической части Сада.

Fig. 7. The pond in historical part of the Garden.

\section{Пункт 4. Коллекция хвойных}

Она складывается из нескольких экспозиций, расположенных влево от главной дороги.

Туэтум (рис. 3, п. 4 а; рис. 9) - коллекция различных форм туи западной (Thuja occidentalis L.); заложена в 1948-1956 гг.

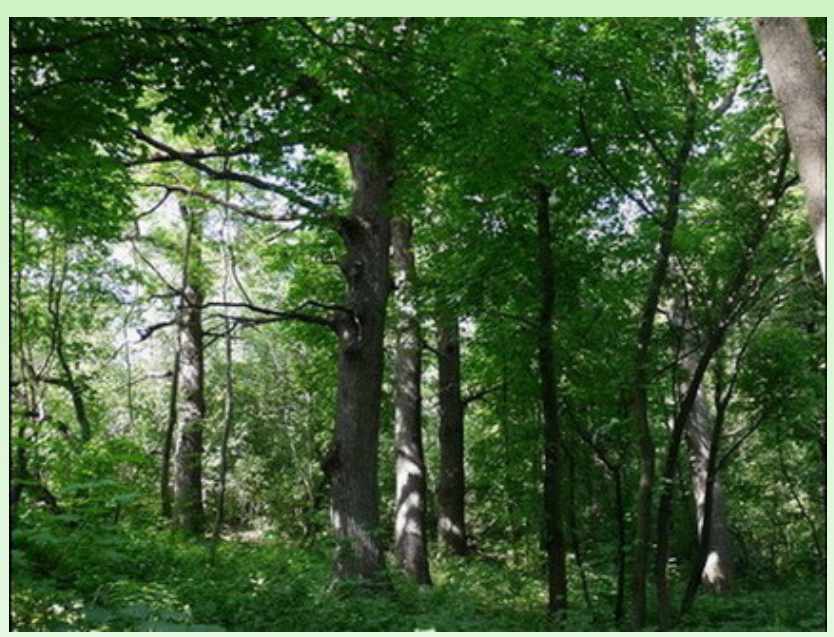

Pис. 8. Quercus robur - Acer platanoides variiherbitas, in situ, в БС ВГУ.

Fig. 8. Quercus robur - Acer platanoides variiherbitas, in situ, in the BG of the VSU.

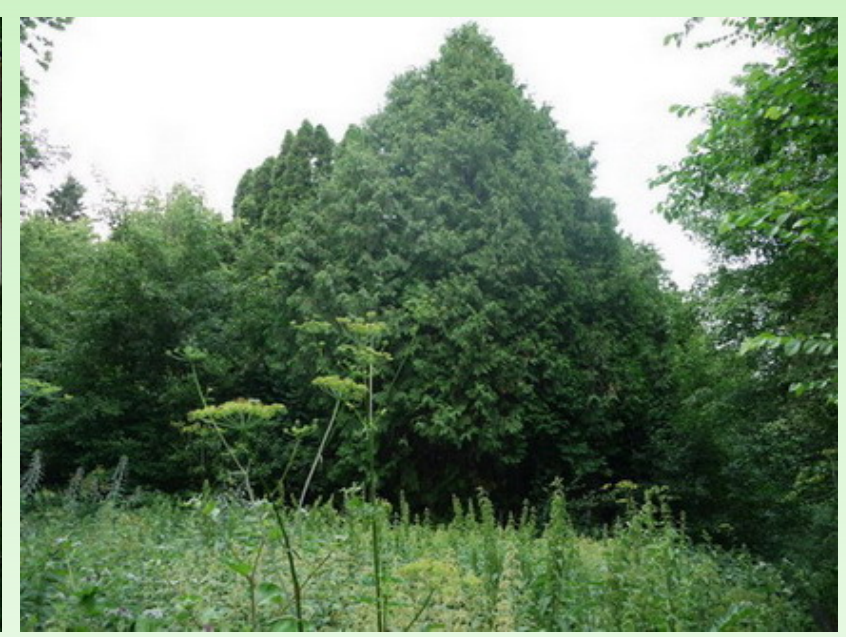

Рис. 9. Туэтум в коллекции хвойных.

Fig. 9. Tuetum in the collection of coniferous.

Сухой бор (рис. 3, п. 4 б; рис. 10) - экспозиция была заложена в послевоенные годы на площади 0,1 га и предоставлена естественным процессам зарастания. В настоящее время кроме сосны обыкновенной (Pinus sylvestris L.), в ней насчитывается более 70 видов растений разных семейств.

Пинетум (рис. 3, п. 4 в; рис. 11) - экспозиция, в которой собраны хвойные семейства сосновых (Pinaceae). В 1958 г. на высоком плато были высажены одновозрастные особи разных видов сосны. Позже экспозицию увеличили за счет посадок экземпляров пихты (Abies), ели (Рicea), тсуги канадской 
(Tsuga canadensis (L.) Carr.), лиственницы сибирской (Larix sibirica Ledeb.). Всего собрано 28 видов, разновидностей и форм представителей сосновых.

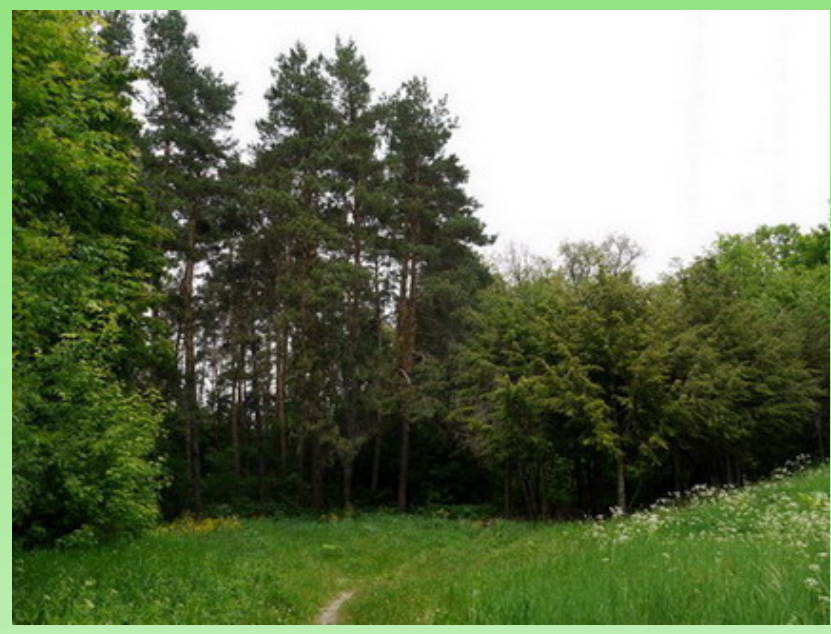

Рис. 10. Экспозиция «Сухой бор».

Fig. 10. The exposition of the "Dry pine forest".

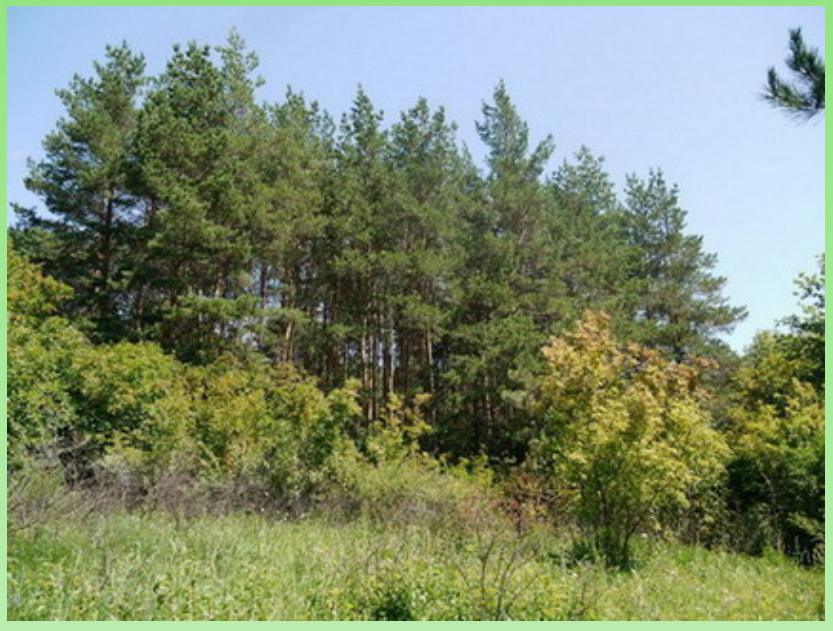

Рис. 11. Пинетум в коллекции хвойных.

Fig. 11. Pinetum in the collection of coniferous.

\section{Пункт 5. Лесополосы (рис. 3, п. 5)}

В 1948 г., после тяжелой войны и жесточайшей засухи 1946-1947 гг., по всей стране по указанию советского правительства начал осуществляться план преобразования природы, который предполагал закладку лесополос, прудов и иных мелиоративных мероприятий. Учитывая важность проблемы, в Ботаническом саду было создано несколько фруктово-дубовых и кленовых полос, расположенных между коллекционными участками.

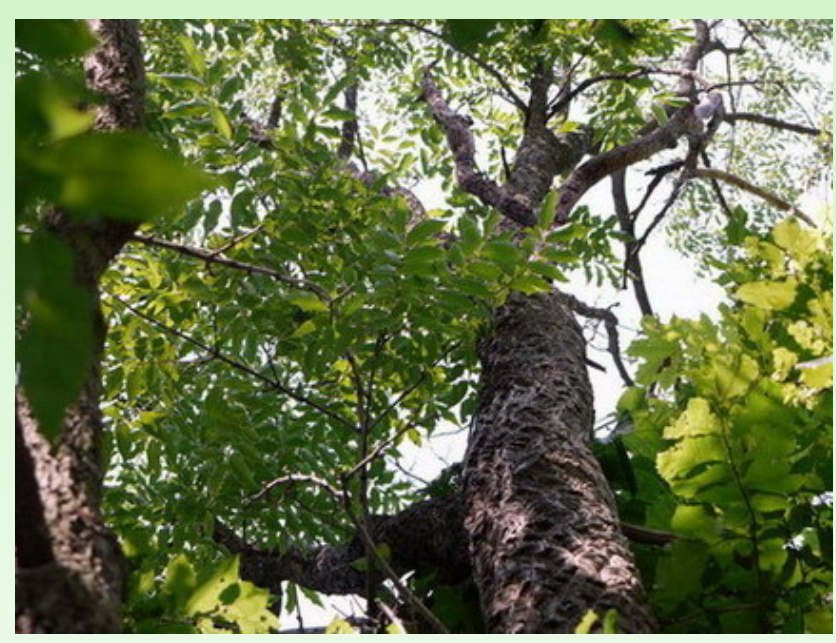

Pис. 12. Phellodendron amurense Rupr. в арборетуме.

Fig. 12. Phellodendron amurense Rupr. in Arboretum

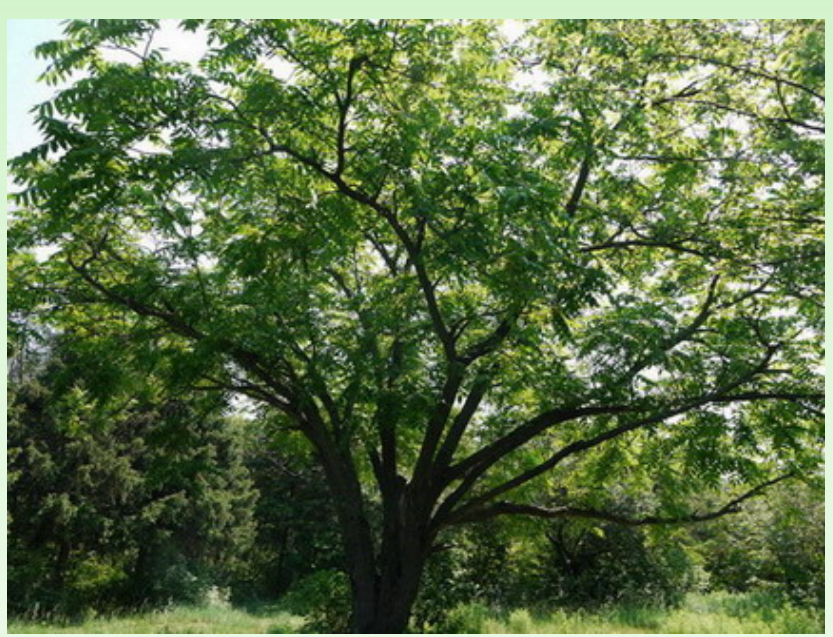

Pис. 13. Juglans mandshurica Maxim. в арборетуме.

Fig. 13. Juglans mandshurica Maxim. in Arboretum.

\section{Пункт 6. Арборетум (рис. 3, п. 6)}

В 1948-1952 гг. в северо-восточной части Ботанического сада С. И. Машкиным, С. В. Голицыным, Н. П. Медведевым была заложена коллекция деревьев и кустарников - арборетум, который размещается на площади 0,75 га. В нем произрастают более 400 видов. Здесь сохраняются очень интересные во 
многих отношениях виды деревьев, которые представлены старыми экземплярами. Это псевдотсуга Мензиса (Pseudotsuga menziesii (Mirb.) Franco), сосна Банкса (Pinus banksiana Lamb.), сосна крымская (Pinus nigra subsp. pallasiana (Lamb.) Holmboe), абрикос маньчжурский (Prunus mandshurica (Maxim.) Koehne), клен ложноплатановый (Acer pseudoplatanus L.), бархат амурский (Phellodendron amurense Rupr.) (рис. 12), орех маньчжурский (Juglans mandshurica Maxim.) (рис. 13) и другие.

Во время экскурсии обращается внимание на видовое разнообразие деревьев и кустарников, на их полезные качества.

\section{Пункт 7. Мичуринский сад (рис. 3, п. 7)}

Как дань памяти выдающемуся разностороннему неутомимому селекционеру И. В. Мичурину по инициативе С. И. Машкина в 50-е годы прошлого столетия была заложена коллекция сортов различных плодовых селекции И. В. Мичурина: груши Бере октябрьская, Бере зимняя Мичурина; яблони бельфлеркитайка, оранжевая и др. Представлены некоторые сорта старинной российской селекции: Антоновка, Добрый крестьянин, Золотой нолик и др.

Пункт 8. Залежные участки (рис. 3, п. 8)

Параллельно сиреневой аллее и мичуринскому саду располагались коллекционные участки растений природной флоры Центрального Черноземья (ЦЧ), в разное время созданные и в разные годы предоставленные естественным процессам (рис. 14). В настоящее время это залежные участки, в формирующихся сообществах которых изучаются фитоценотические возможности сохранившихся видов-интродуцентов, типы их стратегии, констатируется наступление леса на степь.

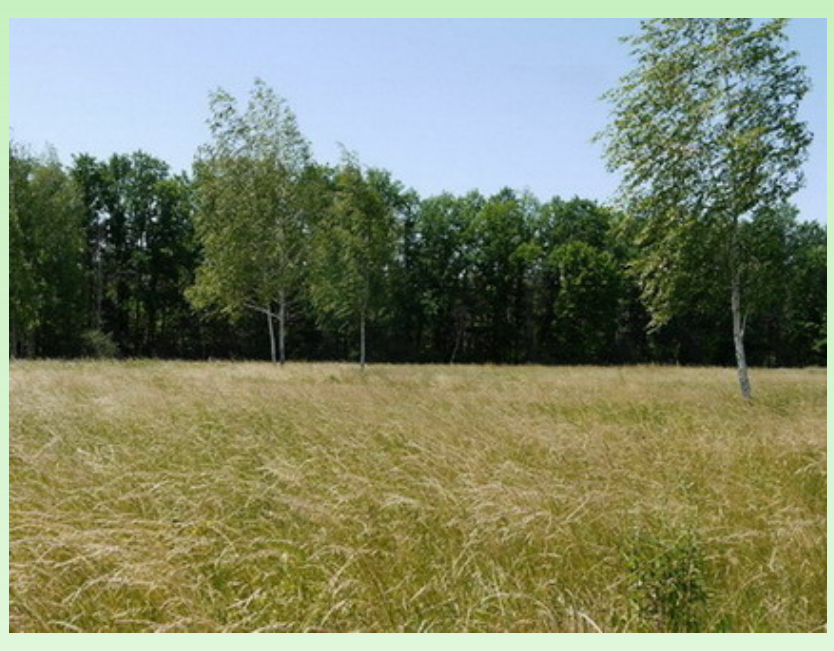

Рис. 14. Участок залежи в БС.

Fig. 14. The plot of fallow land in the BG.

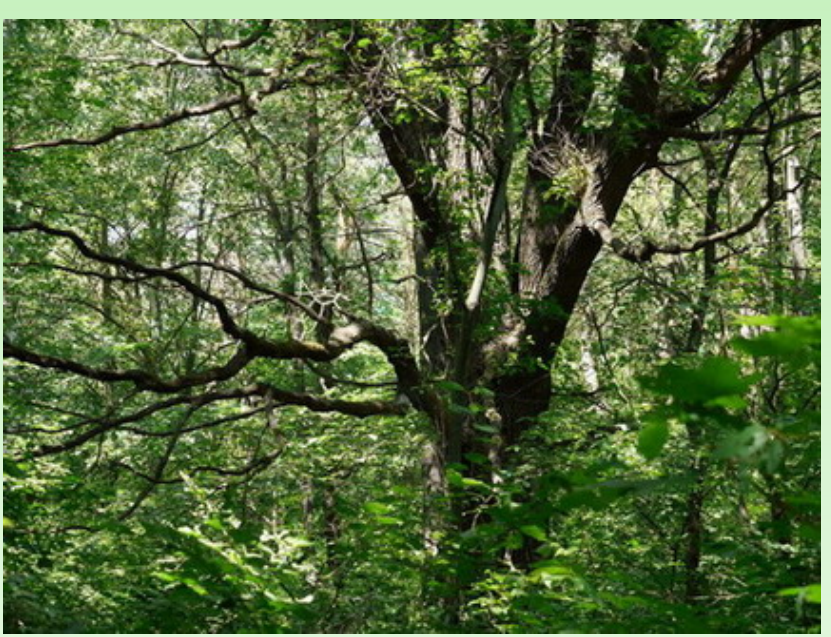

Pис. 15. Quercus robur L. в микрозаповеднике «Заповедная дубрава» БС.

Fig. 15. Quercus robur L. in microconservation "Protected oak association".

Пункт 9. Микрозаповедник «Заповедная дубрава» (рис. 3, п. 9)

Так называется коренная байрачная дубрава, находящаяся в юго-восточной части Сада и расположенная по обеим сторонам глубокой боковой балки. Здесь произрастают самые старые деревья дуба черешчатого (Quercus robur L.) в окружности около 3 м (рис. 15), липы мелколистной (Tilia cordata Mill.), клена остролистного (Acer platanoides L.), к. равнинного (A. campestre L.). Здесь же местами самая высокая сомкнутость крон $(0,9)$. Только здесь были обнаружены, хотя и единично, растения борового комплекса: майник двулистный (Maianthemum bifolium (L.) F. W. Schmidt), вороний глаз (Рагіs quadrifolia L.), костяника (Rubus saxatilis L.). Наличие их дает возможность предположить о существовании в этих местах в начале четвертичного геологического периода сосновых лесов, которые, видимо, с изменением климата уступили место дубравам (Камышев, 1976). 
За дубравой открывается живописная панорама с травянистыми склонами, нисходящими к днищу основной и боковых балок.

Пунк 10. Травянистые склоны (рис. 3, п. 10)

В южной части БС склоны основной балки «Ботаническая», проходящей почти строго с севера на юг, и боковых балок заняты естественными разнотравно-злаковыми лугово-степными сообществами (рис. 16). Флористически они довольно сходны между собой, отличаясь фитоценотическим значением группы константных видов. Около 70 видов растений образуют три яруса с общим проективным покрытием в $100 \%$.

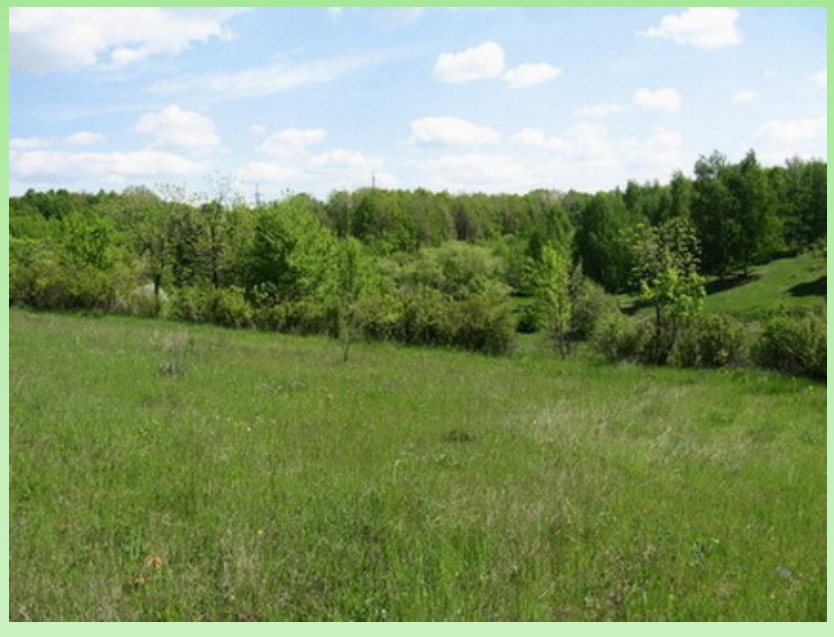

Рис. 16. Травянистые склоны в БС ВГУ.

Fig. 16. Grassy slopes in the BG of the VSU.

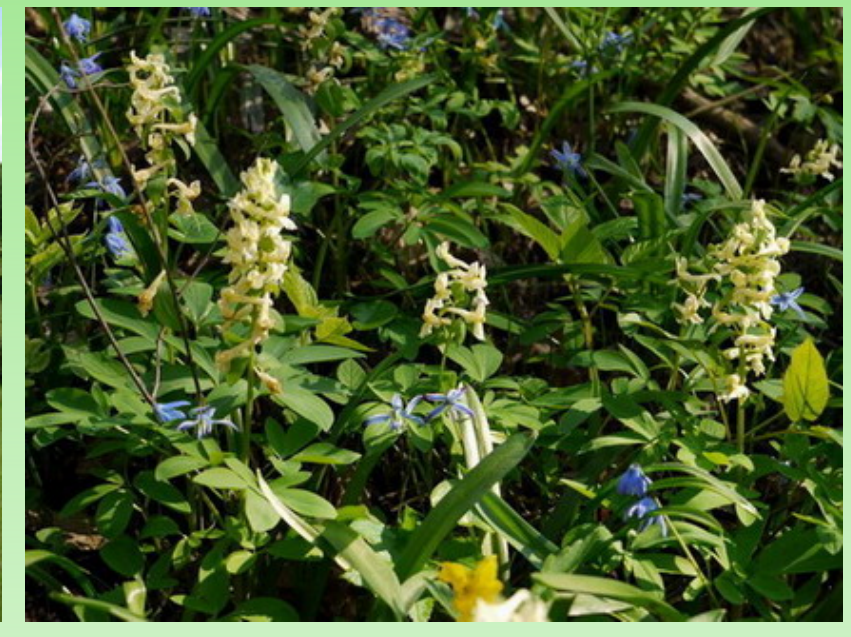

Puc. 17. Corydalis marschalliana (Pall. ex Willd.) Pers., in situ, в БС.

Fig. 17. Corydalis marschalliana (Pall. ex Willd.) Pers., in situ, in the BG.

Пунк 11. Микрозаповедник «Байрачная дубрава» (рис. 3, п. 11)

В юго-западной части БС, в боковой балке, на склоне южной экспозиции произрастает порослевая дубрава. Первые три яруса - это деревья и кустарники (дуб черешчатый (Quercus robur L.), липа мелколистная (Tilia cordata Mill.), клены (Acer), бересклет европейский (Euonymus europaeus L.), 6. бородавчатый (Euonymus verrucosus Scop.), боярышник (Crataegus), лещина обыкновенная (Corylus avellana L.), жимолость обыкновенная (Lonicera xylosteum L.) и др.). В четвертом и пятом ярусах представлено хорошо сформированное сообщество с доминированием осоки волосистой (Carex pilosa Scop.). Только в этой дубраве обнаружены хохлатка Маршалла (Corydalis marschalliana (Pall. ex Willd.) Pers.) (рис. 17), растение-паразит - петров крест (Lathraea squamaria L.) (рис. 18), ломонос прямой (Clematis recta L.), найдены единичные экземпляры венечника ветвистого (Anthericum ramosum L.) и видов, занесенных в Красные книги - ирис безлистный (Iris aphylla L.) и чемерица черная (Veratrum nigrum L.).

Пункт 12. Коллекции диких плодовых и косточковых культур (рис. 3, п. 12)

Старшим научным сотрудником В. С. Нижниковым (1978) в конце 70-х - начале 80-х годов прошлого столетия на склонах южной части балки «Ботаническая» заложены коллекции диких плодовых и косточковых культур. На склоне западной экспозиции представлены разные виды боярышника (Crataegus) из Средней Азии и Северной Америки. Среди них есть крупноплодные виды боярышник Арнольда (Crataegus arnoldiana Sarg.), б. Максимовича (Crataegus maximowiczii C. K. Schneid.). Все виды обильно цветут и плодоносят. На склоне восточной экспозиции располагается коллекция дикорастущих косточковых культур сливы (Prunus), вишни (Cerasus) и другие. Выше, на плато, на площади 4 га, сохраняется сад генетических культур яблони (Malus), груши (Pyrus), рябины (Sorbus). 
Пункт 13. Географический дендропарк (рис. 3, п. 13; рис. 19)

Географический дендропарк закладывался профессором С. И. Машкиным в 1951-1953 годах в средней части балки «Ботаническая», по обе ее стороны, на площади около 9 га. Склоны балки разделили на участки, на которых представили растения разных ботанико-географических зон: Западной Европы, Северной Америки, Японии, Китая, Дальнего Востока, Сибири, Средней Азии, Крыма, Кавказа, Восточной Европы. Здесь посетители знакомятся с наиболее типичными и интересными представителями этих зон, их хозяйственно-ценными качествами.

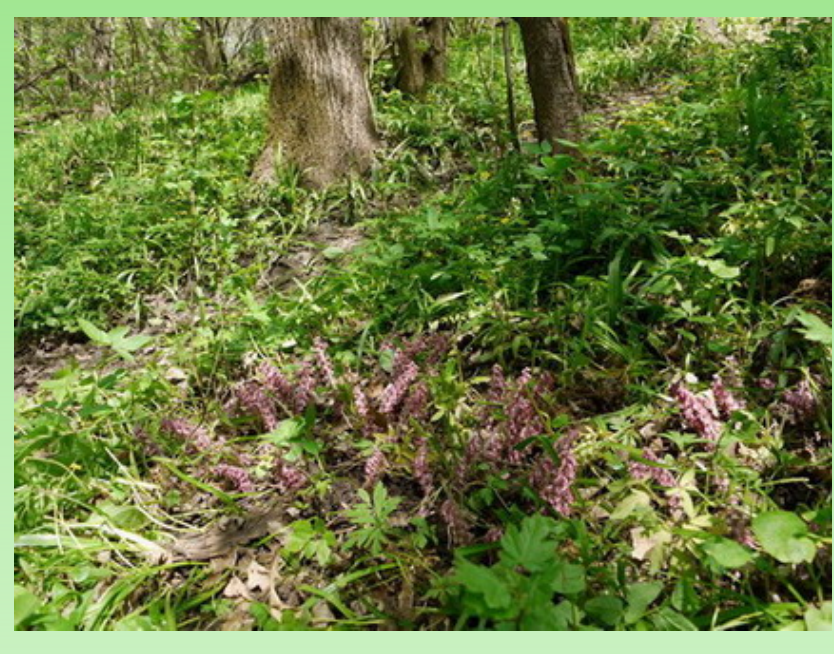

Рис. 18. Lathraea squamaria L., in situ, в БС ВГУ.

Fig. 18. Lathraea squamaria L., in situ, in the BG of the VSU.

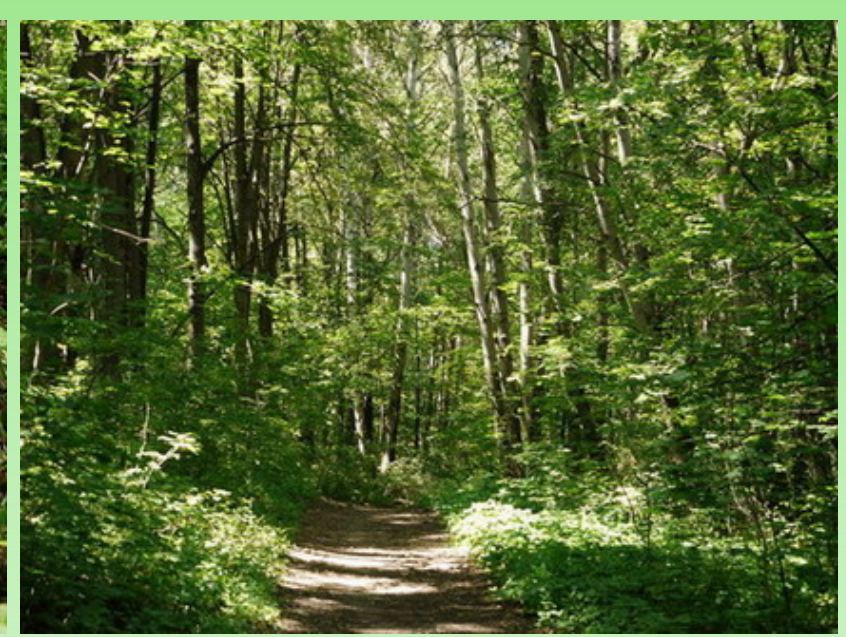

Рис. 19. Аллея в географическом дендропарке.

Fig. 19. Alley in the geographical arboretum.

Кроме изложенного эколого-познавательного маршрута, проводятся более узкие тематические экскурсии по коллекциям и экспозициям, расположенным вокруг административно-лабораторного корпуса. Это оранжерея с тропическими и субтропическими растениями, комплекс коллекций и экспозиций растений природной флоры Центрального Черноземья, питомник фармакопейных растений, розарий с современными сортами роз, коллекция рододендронов, экспозиция с формовым разнообразием деревьев и кустарников. Во время экскурсий, бесед, экологических маршрутов посетителям Ботанического сада на конкретных примерах дается представление о разнообразии мировой флоры, о растительности Центрального Черноземья, подчеркивается значение зеленых растений в целом и конкретных видов в отдельности, необходимость сохранения генетических ресурсов и экологического равновесия в природе, воспитательная, образовательная и эстетическая роль растений.

Помимо традиционных аспектов работы с коллекциями, в Ботаническом саду Воронежского государственного университета определены дальнейшие перспективы развития и реализации экологического ресурса. Они касаются новых подходов к проведению научных исследований и применению их в научно-образовательном процессе (Калаев, Карпова, 2012). Разрабатывается программа по предупреждению появления новых фитоинвазий и способах борьбы с уже внедрившимися чужеродными видами. Создается банк семян хозяйственно-ценных, редких и охраняемых видов (Сафонова, 2011). Проводятся испытания новых химических стимуляторов роста, синтезированных на кафедре органической химии ВГу, на представителях рода Rhododendron, Salvia, Tagetes и др. Выполняются работы по микроклональному размножению ценных редких видов, таких как Daphne cneorum L., Salvia glutinosa L. Изучаются молекулярно-генетические особенности видов рода Rhododendron.

Упоминаемые выше направления научно-исследовательской работы выполняются в рамках тематических планов Воронежского государственного университета. 
Ботанический сад ВГУ участвует в научных международных форумах, организует очные и заочные конференции с международным участием. По результатам научных исследований изданы монографии (Карташева и др, 2008; Карташева и др., 2010; Воронин и др., 2014 и другие), учебные и справочные пособия (Лепешкина и др., 2011; Девятова и др., 2012). Для популяризации знаний о растениях Ботанического сада, их практическом применении, о проблемах и достижениях сотрудники выступают по местному радио, в местных и центральных периодических изданиях, проводят многочисленные консультации, мастер-классы по телевидению. Ботанический сад ежегодно принимает участие в выставках-ярмарках цветов, плодов и овощей, проводимых в г. Воронеж.

$* * *$

Экологический ресурс Ботанического сада, состоящий из ландшафтов с дубравами и луговостепными склонами с их флорой, фауной и растительностью, рукотворными коллекциями и экспозициями интродуцентов, а также лабораториями, гербарием, библиотекой и системой обработки информации является базой для осуществления научной, образовательной и эколого-просветительской деятельности в БС. Он представляет собой большую лабораторию по изучению биоты и среды ее обитания, по хранению и сбережению биоразнообразия планеты, местом экскурсионнопросветительской работы.

В реализации экологического ресурса БС принимают участие студенты и преподаватели биологопочвенного, географического и фармацевтического факультетов Воронежского госуниверситета. Во время практических, лабораторных и полевых занятий у студентов развивается интерес к изучению жизни растений, вырабатываются трудовые навыки.

В Ботаническом саду разработаны и функционируют эколого-познавательные тропы. Наиболее протяженный маршрут состоит из 13 пунктов. Он охватывает многие природные экосистемы и старовозрастные дендрологические коллекции. Другие маршруты проходят по коллекциям, расположенным в районе административно-лабораторного корпуса и включают розарий, оранжерею, коллекции декоративно-травянистых, лекарственных растений, декоративных деревьев и кустарников, теневой сад, ландшафтно-флористический комплекс природной флоры Центрального Черноземья.

Во время экскурсий, бесед, экологических маршрутов у посетителей БС на конкретных примерах формируется представление о разнообразии мировой фллоры, о растительности ЦентральноЧерноземного региона, о пользе растений, подчеркивается воспитательная, образовательная и эстетическая роль растений.

В Ботаническом саду разрабатываются новые подходы к научно-исследовательской работе с дальнейшим применением их в учебно-образовательном процессе.

Во всех экосистемах БС ВГУ отмечается рост рекреационной нагрузки из-за возрастающего повсеместно антропогенного воздействия. В этой связи обязательной нитью учебных практик, бесед, экскурсий, экологических маршрутов проходит тема бережного отношения ко всем природным объектам, сохранения генетических ресурсов, экологического равновесия и рационального природопользования, осуществляется формирование экологической культуры.

\section{Литература}

Андреев Л. Н., Бер М. Н., Егоров А. А., Камелин Р. В., Лурье Е. А., Прохоров А. А., Стриханов М. Н., Селиховкин А. В. Ботанические сады и дендрологические парки высших учебных заведений [Botanical Gardens and dendrological parks of higher educational institutions] // Hortus bot. 2006. T. 3. 22 с. URL: http://hb.karelia.ru/.

Воронин А. А., Муковнина З. П., Комова А. В., Николаев Е. А. Ботанический сад им. проф. Б. М. КозоПолянского Воронежского госуниверситета: научный, образовательный и экскурсионнопросветительский ресурсы. [The Botanical Garden named after of professor В. М. Kozo-Polyansky of the Voronezh State University: scientific, educational, excursion and learning resources] Воронеж, 2014.140 c.

Воронин А. А., Николаев Е. А., Комова А. В. Ботанический сад имени профессора Б. М. Козо-Полянского Воронежского государственного университета - центр интродукции и сохранения биоразнообразия 
растений // Вестник Воронежского государственного университета. Сер. Проблемы высшего образования. [The Botanical Garden named after of professor B. M. Kozo-Polyansky of the Voronezh State University as the main center of plant introduction and biodiversity conservation // Proceedings of Voronezh State University Series: Problems of Higher Education] Воронеж, 2013. № 1. C. 185-191.

Девятова Т. А., Калаев В. Н., Воронин А. А., Лепешкина Л. А. Учебная практика по созданию сети экологических маршрутов в Ботаническом саду им. проф. Б. М. Козо-Полянского Воронежского госуниверситета: учеб. пособие для вузов. [In-service education program for building tourist network in the Botanical Garden named after of professor B. M. Kozo-Polyansky of the Voronezh State University: textbook for high schools] Воронеж, 2012. 49 c.

Калаев В. Н., Карпова С. С. Основные направления научно-исследовательской работы ботанического сада имени профессора Б. М. Козо-Полянского Воронежского государственного университета // Современные проблемы интродукции и сохранения биоразноообразия растений: материалы 2-й Междунар. науч. конф., посвящ. 75-летию Ботсада им. проф. Б. М. Козо-Полянского и 100-летию со дня рожд. проф. С. И. Машкина. [Basic trends in research of the Botanical Garden named after of professor B. M. Kozo-Polyansky of the Voronezh State University // Contemporary problems of plant introduction and biodiversity conservation: proceedings of the 2 International Conference is dedicated to the 75-th anniversary of the Botanical Garden named after of professor B. M. Kozo-Polyansky of the Voronezh State University and to a centenary anniversary of the birth of professor S. I. Mashkin] Воронеж, 2012. C. 10-20.

Камышев Н. С., Хмелев К. Ф. Растительный покров Воронежской области и его охрана. [The vegetation cover of the Voronezh region and its protection] Воронеж, 1976. 184 c.

Карташева Л. М., Комова А. В., Кузнецов Б. И., Муковнина З. П., Николаев Е. А., Сафонова О. Н., Шестопалова В. В., Шипилова В. Ф., Щеглов Д. И. Каталог растений ботанического сада им. проф. Б. М. Козо-Полянского Воронежского госуниверситета. [The Catalog of the plants growing in the Botanical Garden named after of professor B. M. Kozo-Polyansky of the Voronezh State University] Воронеж, 2008. 183 c.

Карташева Л. М., Муковнина З. П., Шипилова В. Ф., Комова А. В., Кузнецов Б. И., Сафонова О. Н., Николаев Е. А. Интродукция редких и исчезающих растений в Центральном Черноземье. [Plant introduction of rare and endangered species in Black Soil Area] Воронеж, 2010. 212 с.

Комова А. В., Муковнина 3. П., Воронин А. А. Коллекции ботанического сада Воронежского государственного университета и их роль в научно-образовательном процессе // Ботанические коллекции - национальное достояние России: сб. науч. статей Всероссийской (с международным участием) научной конференции, посвященной 120-летию Гербария имени И. И. Спрыгина и 100-летию Русского ботанического общества. [Collections of plants of the Botanical Garden of the Voronezh State University and its implications for the scientific and educational process // Botanical collections are national resources of Russia: a book of articles of science of all-Russian conference with international participation is dedicated to the 120-th anniversary of the Herbarium by named after of I. I. Sprigin and to a centenary celebration of Russian botanical society] Пенза, 2015. C. 248-250.

Кузеванов В. Я., Никулина Н. А. К определению термина «экологические ресурсы» // Вестник Красноярского государственного аграрного университета [Towards the definition of the term 'Ecological Resources' // The Bulletin of KrasGAU] Красноярск, 2016. № 5 (116). С. 77-83.

Кузеванов В. Я., Сизых С. В. Ресурсы Ботанического сада Иркутского государственного университета: научные, образовательные и социально-экологические аспекты. [The resources of the Botanical Garden of Irkutsk State University: scientific, educational and socio-environmental aspects] Иркутск, 2005. 243 с.

Кузнецов Б. И., Негробов В. В., Негробова О. И. О коллекции лекарственных растений Ботанического сада Воронежского государственного университета // Ботанические коллекции - национальное достояние России: сборник научных статей Всероссийской (с международным участием) научной конференции, посвященной 120-летию Гербария имени И. И. Спрыгина и 100-летию Русского ботанического общества, г. Пенза, 17-19 февраля 2015 г. [About the collection of medicinal plants of the Botanical Garden of Voronezh State University // Botanical collections are national resources of Russia: a book of articles of science of all-Russian conference with international participation is dedicated to the 120-th 
anniversary of the Herbarium by named after of I. I. Sprigin and to a centenary celebration of Russian botanical society] Пенза, 2015. С. 257-258.

Лепешкина Л. А., Воронин А. А. Адвентивный компонент флоры Ботанического сада Воронежского госуниверситета // Флора и растительность Центрального Черноземья - 2014: материалы научной конференции. [Adventive component of flora of the Botanical Garden of Voronezh State University // Flora and vegetation in Black Soil Area - 2014: proceedings of research conference] Kypck, 2014. C. 198-201.

Лепешкина Л. А., Калаев В. Н., Девятова Т. А., Воронин А. А. Полевая практика по биогеографии с основами геоботаники и флористики в ботаническом саду им. проф. Б. М. Козо-Полянского Воронежского государственного университета: учеб. пособие для вузов. [Field practice for biogeography with the basics of geobotany and floristics in the Botanical Garden named after of professor B. M. KozoPolyansky of the Voronezh State University: textbook for high schools] Воронеж, 2011. 53 c.

Лепешкина Л. А., Муковнина 3. П., Комова А. В., Воронин А. А. Микрозаповедники ботанического сада как ценные ботанические объекты // Флора и растительность Центрального Черноземья - 2012: материалы науч. конференции. [Microreserves as a high-priority assets of the Botanical Garden // Flora and vegetation in Black Soil Area - 2012: proceedings of research conference] Kypck, 2012. C. 127-131.

Машкин С. И. Биоэволюционные основы и методы интродукции и селекции растений // Биоэволюционные основы и методы интродукции и селекции растений: сб. науч. тр. [Bio-evolutionary foundation and methods of introduction and selection of plants // Bio-evolutionary foundation and methods of introduction and selection of plants: a book of scientific papers] Воронеж, 1994. C. 5-14.

Международная программа ботанических садов по охране растений. [Botanic Gardens Conservation International] M. BGCI. 2000. 57 c.

Муковнина 3. П. Дикорастущая флора Ботанического сада Воронежского университета // Интродукция растений в Центральном Черноземье. [Wild-growing flora of the Botanical Garden of Voronezh State University // Plant introduction in Black Soil Area] Воронеж, 1988. C. 103-119.

Муковнина 3. П., Воронин А. А., Комова А. В. Коллекция "Систематикум" природной флоры Центрального Черноземья в ботаническом саду Воронежского госуниверситета // Актуальные вопросы плодоводства и декоративного садоводства в XXI веке: материалы международной научно-практической конференции, посвященной 120-летию основания института и 80-летию основания сада-музея "Дерево Дружбы". [Sistematikum collection of natural flora of the Black Soil Area in the Botanical Garden of the Voronezh State University // Current issues of fruit growing and ornamental horticulture in the XXI century: proceedings of the International scientific-practical conference is dedicated to the 120-th anniversary of the founding of the Institute and to the 80-th anniversary of the founding of the garden-museum "Tree of Friendship"] Сочи, 2014. C. $142-148$.

Муковнина 3. П., Комова А. В., Минаков Н. В. Лесные и кустарниковые экосистемы Ботанического сада ВГУ // Вестник ВГУ. Серия: Химия. Биология. Фармация. [Woodland and fruticous ecosystems of the Botanical Garden of the VSU // Proceedings of Voronezh State University Series: Chemistry. Biology. Pharmacy] Воронеж, 2005. № 1. C. 122-127.

Нижников В. С., Дудкин Г. И. Перспективы интродукции новых видов плодовых и ягодных растений в ЦЧО в связи с их зимостойкостью. [Prospects for introduction of a new fruit and berry plant species in Black Soil Area because of its winter resistance] Воронеж, 1978. 35 c.

Николаев Е. А. В царстве растений. [In the plant kingdom] Воронеж, 1977. 113 с.

Сафонова О. Н. Формирование банка семян растений региональной и мировой флоры // Вестник Воронежского государственного университета. Сер. География. Геоэкология. [The formation of a seed Bank of plants of regional and world flora // Proceedings of Voronezh State University. Series: Geography. Geoecology] Воронеж, 2011. № 1. C. 70-71.

Щеглов Д. И., Муковнина 3. П. Мониторинг природных экосистем ботанического сада Вгу // Современные проблемы интродукции и сохранения биоразнообразия: матер. междунар. науч. конф. [Monitoring of 
natural ecosystems of the Botanical Garden of VSU // Modern problems of introduction and conservation of biodiversity: proceedings of the International scientific conference] Воронеж, 2007. C. 65-68.

\title{
Ecological Resource and its realization in the Botanical Garden of the Voronezh State University
}

\author{
VORONIN \\ Voronezh State University, vsubotsad@mail.ru \\ Andrey
}

MUKOVNINA

Zoya

KOMOVA

Alla

\section{Keywords:}

science, education, social activities, ecological resources, plant

introduction, scientific and educational potential, botanical garden, natural and artificial ecosystems, ecological path, culture collections, shore excursion
Voronezh State University, botsad.vsu@mail.ru

Voronezh State University, botsad.vsu@mail.ru

\begin{abstract}
Annotation:
The article considers components of environmental resource of the Botanical Garden of Voronezh State University in connection with its introductional activity and scientific and educational process. The components include collections, expositions, area of natural vegetation typical of forest-steppe zone. The article provides examples of ecological resource use that is study of vascular plants flora, mosses, lichens, fungi, fauna and of ecological and biological characteristics of collection plants, with priority for rare and endangered species. There is also description of field training and work practices, excursions, talks. Special attention is given to Botanical Garden potential in tourist and excursion arrangement as well as development of ecological vision. 13 items of environmental and educational path were identified and described which include all natural ecosystems and old dendrology collections, fallow lands. The excursions themes for all other collections of the Botanical Garden were named. Real perspectives for science research were defined.
\end{abstract}

Цитирование: Воронин А. А., Муковнина 3. П., Комова А. В. Экологический ресурс и его реализация в Ботаническом саду Воронежского государственного университета // Hortus bot. 2016. T. 11, URL: http://hb.karelia.ru/journal/article.php?id=3642. DOI: 10.15393/j4.art.2016.3642

Cited as: Voronin A. A., Mukovnina Z. P., Komova A. V. "Ecological Resource and its realization in the Botanical Garden of the Voronezh State University" // Hortus bot. 11, (2016): DOI:

10.15393/j4.art.2016.3642 